\title{
ENERGETSKA SAMOZADOSTNOST PLANINSKIH POSTOJANK V TRIGLAVSKEM NARODNEM PARKU
}

\author{
Urban Jensterle, univ. dipl. geograf \\ Selo pri Bledu 4I c, SI-4260 Bled \\ e-mail: urban.jensterle@gmail.com \\ Strokovni članek \\ COBISS 1.04 \\ DOI: 10.4312/dela.40.12.215-231
}

\section{Izvleček}

V oskrbi planinskih postojank v Triglavskem narodnem parku z električno energijo je prišlo v zadnjih dvajsetih letih do izrazitega prehoda iz fosilnih virov na obnovljive vire energije. V poletju 2012 so imele vse preučevane postojanke nameščene sončne celice, nekatere tudi vetrne generatorje. Na podlagi analize energetske oskrbe postojank, upoštevajoč njihove potrebe po energiji, električno oskrbo in toplotno oskrbo, smo izdelali tipizacijo. Za postojanke, ki za proizvodnjo električne energije še vedno uporabljajo fosilna goriva, smo predlagali ukrepe in izpostavili prednostne naloge.

Ključne besede: obnovljivi viri energije, sončna energija, planinska postojanka, Triglavski narodni park

\section{ENERGY SELF-SUFFICIENCY OF MOUNTAIN HUTS IN TRIGLAV NATIONAL PARK}

\begin{abstract}
The electricity supply of mountain huts in Triglav National Park has changed in last 20 years. It is no longer based on fossil fuels but on renewable energy sources. In summer 2012, all analyzed mountain huts had solar cells, some also used wind energy. We are presenting a typology of mountain huts according to energy supply, their needs for energy, electricity and heat supply. Proposals and priorities were set for those mountain huts who still use fossil fuels for electricity production.
\end{abstract}

Key words: renewable energy sources, solar energy, mountain hut, Triglav National Park 


\section{UVOD}

Pohodništvo in planinstvo sodita med najbolj priljubljene oblike rekreacije v Sloveniji. Pod okriljem krovne organizacije, Planinske zveze Slovenije (PZS), ki je v začetku leta 2013 združevala 278 planinskih društev, je bilo pohodnikom na voljo več kot 1660 planinskih poti s skupno dolžino več kot $9000 \mathrm{~km}$ in 176 planinskih postojank, ki obiskovalcu nudijo zavetje, prenočišče, hrano in pijačo (Predstavitev. Planinska zveza Slovenije, 2013). Pojem planinske postojanke združuje tri tipe planinskih objektov, in sicer planinske koče, zavetišča in bivake (Seznam koč, zavetišč ..., 2013). Največja zgostitev tako planinskih poti kot tudi planinskih postojank je v Triglavskem narodnem parku (TNP).

Osrednje poslanstvo Javnega zavoda Triglavski narodni park je ohranjanje narave (Triglavski narodni park, 2013). Zavod med drugim bdi tudi nad planinskimi društvi, ki pod okriljem PZS izvajajo ukrepe za učinkovitejše delovanje vsake posamezne planinske postojanke - predvsem glede oskrbe $\mathrm{z}$ energijo in vodo, ravnanja $\mathrm{z}$ odpadnimi vodami ter odstranjevanja odpadkov.

Najbolj aktivno se v slovenskem prostoru z vplivom planinskih postojank na okolje ukvarja Gospodarska komisija PZS, ki že od leta 1991 uspešno uresničuje usmeritev $\mathrm{Na}$ redimo naše gore okolju prijazne, v sklopu katere med drugim spodbujajo tudi prehod na čistejše vire energije (Šarkezi, 2009). Več izdanih smernic, del in direktiv teži k energijski samozadostnosti planinskih postojank. Nekoliko manj iz raziskovalnega, vendar toliko bolj iz usmeritvenega vidika, je pomembno delo Smernice za okolju primerno tehniko na planinskih kočah: načrtovanje, izgradnja, obratovanje, vzdrževanje, ki ga je leta 2011 izdala PZS (Deubler in sod., 2011). Ravno tako v okolju prijazno razvojno smer usmerjajo planinske postojanke s projektom Okolju prijazna koča (Dretnik, 2012). Delo se osredotoča na njihovo energijsko samooskrbo, s poudarkom na električni energiji.

\section{OBRAVNAVANE PLANINSKE POSTOJANKE}

Po podatkih PZS je bilo aprila 2012 na območju Julijskih Alp 58 planinskih koč, zavetišč in bivakov (Seznam koč, zavetišč ..., 2013). V prvem koraku smo iz nadaljnje analize izključili planinske postojanke izven TNP, v drugem planinske postojanke III. kategorije (nekoč imenovane nižinske planinske postojanke), v tretjem planinske postojanke I. (visokogorske) in II. (sredogorske) kategorije, ki so priključene na javno električno omrežje, v četrtem pa bivake, ki so neoskrbovana planinska zavetišča. Namen zadnjih je, da omogočajo zasilno prenočišče, zato investicije v energetsko oskrbo niso prioriteta. V analizo je bilo tako vključenih 18 planinskih postojank (Jensterle, 2013).

\section{METODE DELA}

Vse obravnavane planinske postojanke smo obiskali poleti 2012. Na podlagi intervjujev z njihovimi oskrbniki in gospodarji planinskih društev smo izdelali temeljito analizo energetske (električne in toplotne) oskrbe in na njeni osnovi tipologijo planinskih postojank. 
Slika 1: Preučevane planinske postojanke po varstvenih območjih Triglavskega narodnega parka (2012)

Figure 1: Analyzed mountain huts in Triglav National Park by conservation zones (2012)

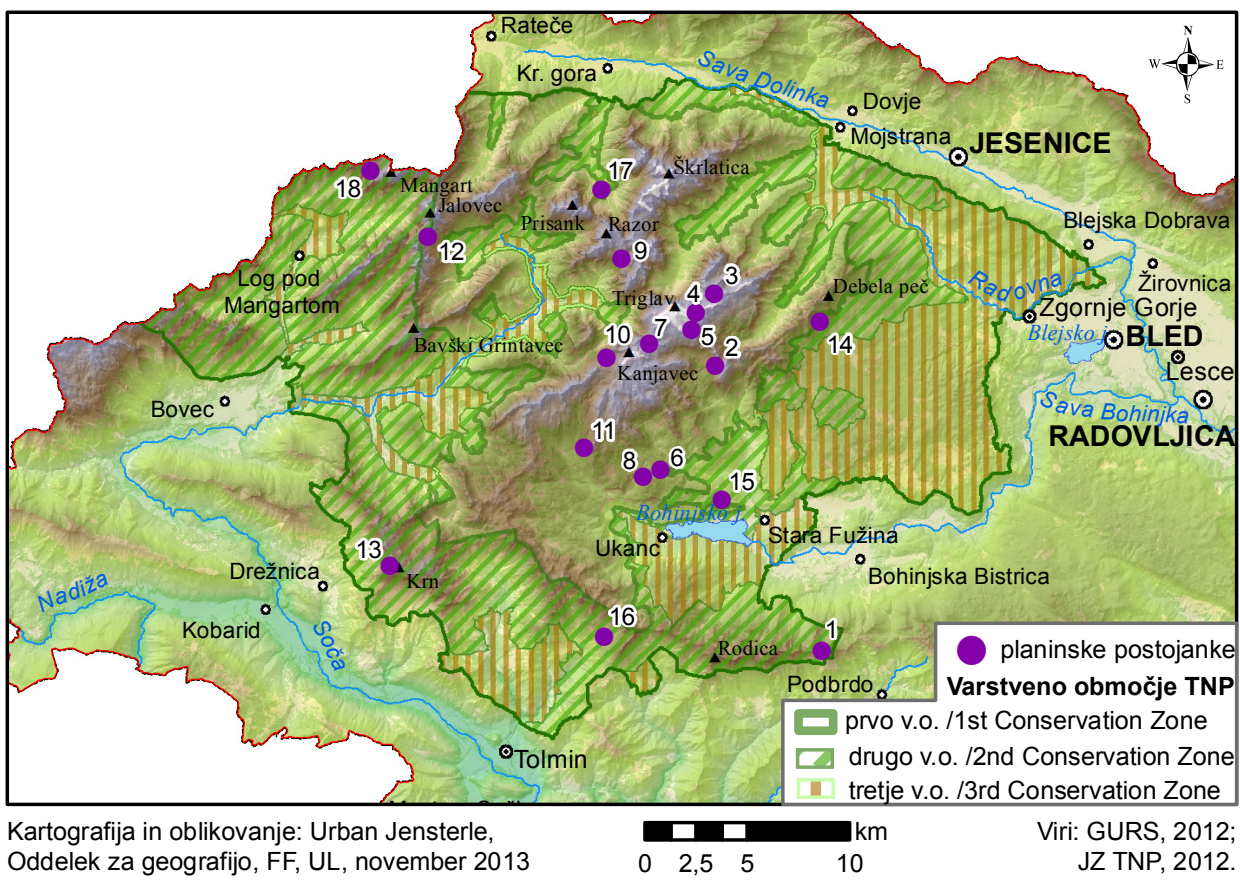

Legenda/Legend: 1 Dom Zorka Jelinčiča na Črni prsti; 2 Vodnikov dom na Velem polju; 3 Dom Valentina Staniča; 4 Triglavski dom na Kredarici; 5 Dom Planika pod Triglavom; 6 Koča na Planini pri Jezeru; 7 Koča na Doliču; 8 Bregarjevo zavetišče na planini Viševnik; 9 Pogačnikov dom na Kriških podih; 10 Zasavska koča na Prehodavcih; 11 Koča pri Triglavskih jezerih; 12 Zavetišče pod Špičkom; 13 Gomiščkovo zavetišče na Krnu; 14 Blejska koča na Lipanci; 15 Kosijev dom na Vogarju; 16 Koča na planini Razor; 17 Koča v Krnici; 18 Koča na Mangartskem sedlu

Delo temelji na fizičnogeografskem metodološkem pristopu (Plut, 2004), le da se namesto na posledice človekovega negativnega učinka na okolje zaradi uporabe fosilnih goriv osredotočamo na opredelitev možnosti uporabe obnovljivih virov energije kot okolju prijaznejše rešitve. V raziskavi predlagamo planinskim postojankam, ki uporabljajo fosilna goriva, rešitve na osnovi sončne in vetrne energije.

Za izračun jakosti in trajanja Sončevega obsevanja na lokacijah analiziranih planinskih postojank smo uporabili orodje Točkovno Sončevo obsevanje (Points Solar Radiation) iz programske opreme ESRI (ArcGIS). Največja pomanjkljivost modela pri določanju trajanja Sončevega obsevanja je bila neupoštevanje oblačnosti - vrednosti bi veljale v primeru celoletnega sončnega vremena. Razmerja med izračunanimi vrednostmi 
(ArcGIS) in pridobljenimi vrednostmi (ARSO) za izbrane točke (meteorološke postaje) so bila približno enaka. Povprečje teh razmerij smo projicirali na ostale planinske postojanke in s tem dobili vrednosti, ki predstavljajo najboljši približek dejanskemu stanju na terenu in so torej sprejemljive za nadaljnjo analizo (Jensterle, 2013).

Ocena samozadostnosti z električno energijo zgolj z rabo obnovljivih virov energije je bila narejena na podlagi izračunov o porabi električne energije in proizvodnji električne energije iz obnovljivih virov energije. Porabo električne energije smo izračunali iz podatkov o porabi v električnih napravah v planinskih postojankah, pridobljenih z intervjuji (2012). Pri izračunu proizvodnje električne energije iz vetrne energije smo izhajali iz moči vetrnega generatorja in deleža časa z ugodnim vetrom. Proizvodnjo električne energije iz sončne lahko računamo na dva načina: pri izračunu na osnovi vršne moči sončnih celic smo upoštevali temperaturo in usmeritev sončnih celic ter izgube na regulatorjih polnjenja in napetosti. Izračun na osnovi površine sončnih celic in njihovega izkoristka se zaradi pomanjkljivosti uporablja le izjemoma, saj rezultati niso točni, a vseeno okvirno pravilni (Jensterle, 2013). V obeh izračunih smo upoštevali rezultate izračunov jakosti in trajanja Sončevega obsevanja za vsako planinsko postojanko, ki smo jih dobili z uporabo orodij GIS.

V zaključni fazi smo za planinske postojanke, ki zgolj z rabo obnovljivih virov energije niso bile samozadostne, predlagali ustrezne rešitve. Te smo iskali v knjigi Smernice za okolju primerno tehniko na planinskih kočah (Deubler in sod., 2011) in primerih dobre prakse iz avstrijskega in nemškega okolja (Menz, 2008). Izvedli smo tudi preračune, ali bi postojanke lahko postale samozadostne zgolj z uporabo obnovljivih virov energije, če bi sedanje električne naprave zamenjali z energijsko najvarčnejšimi izvedbami.

\section{OSKRBA PLANINSKIH POSTOJANK Z ELEKTRIČNO ENERGIJO}

V obdobju 1992-2012 so obnovljivi viri energije opazno pridobili na pomenu $\mathrm{v}$ preskrbi planinskih postojank z električno energijo. Če je še leta 1992 deset postojank pridobivalo elektriko izključno iz fosilnih goriv, je imela v letu 1999 večina (z izjemo Koče na Mangartskem sedlu) nameščene sončne celice. Triglavski dom na Kredarici in Gomiščkovo zavetišče na Krnu sta za oskrbo z elektriko uporabljala tudi vetrni generator. V poletju 2012 je Koča na Mangartskem sedlu celo vse stavila na obnovljive vire energije in električni generator odstranila iz koče. Vetrni generator so v energetski koncept vključili v štirih primerih: Triglavski dom na Kredarici, Koča na Doliču, Dom Valentina Staniča in Koča na Mangartskem sedlu. Vetrnico Gomiščkovega zavetišča na Krnu je sunkovit veter pred nekaj leti uničil. Zaradi višjih stroškov namestitve nove v bolj zavetrni legi, se je Planinsko društvo Nova Gorica rajši odločilo za dodatne sončne celice (Poje, 2000; Intervjuji, 2012).

Za razliko od avstrijskih in nemških Alp se vodna energija kot obnovljiv vir energije v Julijskih Alpah zaradi kraškega površja ne uporablja. 


\begin{tabular}{|c|c|c|c|c|c|c|c|c|c|c|c|c|c|c|c|c|c|c|c|}
\hline $\begin{array}{l}\mathbf{\Xi} \\
0 \\
2\end{array}$ & 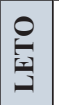 & $\overrightarrow{\widetilde{\nu}}$ & $\stackrel{\beth}{\beth}$ & $\begin{array}{l}0 \\
\infty \\
\infty\end{array}$ & $\stackrel{ \pm}{\Xi}$ & $\begin{array}{c}\mathbb{1} \\
\infty \\
-1\end{array}$ & さે & $\overrightarrow{\mathcal{I}}$ & 跑 & $\stackrel{\check{\Omega}}{\Xi}$ & $\widehat{\widehat{6}}$ & $\stackrel{\Xi}{\exists}$ & 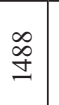 & $\hat{n}$ & 点 & $\begin{array}{l}\qquad \\
\infty \\
\infty\end{array}$ & 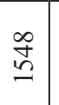 & $\widetilde{\sigma}$ & 于 \\
\hline$\sim$ & 됨 & ปี & 6 & $\stackrel{\infty}{\infty}$ & ¿ & I & 苛 & 孛 & $\infty$ & & $\approx$ & $\infty$ & $\vec{\infty}$ & $\Xi$ & $\infty$ & $\stackrel{1}{\infty}$ & $\infty$ & 0 & $\infty$ \\
\hline$\stackrel{3}{3}$ & $\frac{1}{7}$ & 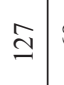 & aे & aे & $\hat{\varrho}$ & $\cong$ & $\widetilde{\sigma}$ & $n$ & 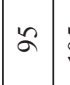 & $\approx$ & $a$ & \& & $\infty$ & $\widehat{\cong}$ & 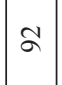 & $\Xi$ & สू & 0 & $\infty$ \\
\hline 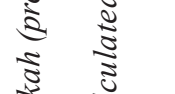 & $\frac{1}{0}$ & 足 & \$ & $\bar{g}$ & 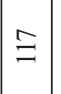 & $\exists$ & $\vec{\infty}$ & $\bar{\sigma}$ & $\stackrel{ }{ }$ & $\stackrel{\Xi}{工}$ & $\Xi$ & 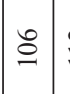 & $\cong$ & 守 & $\cong$ & 兄 & 음 & $\bar{\lambda}$ & $\Xi$ \\
\hline is & 空 & $\stackrel{ \pm}{I}$ & 至 & 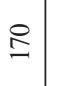 & $\begin{array}{l}0 \\
\end{array}$ & $\overrightarrow{0}$ & $\cong$ & ఏे & I & $\tilde{ก}$ & $\exists$ & $\stackrel{ \pm}{\Xi}$ & $\begin{array}{l}0 \\
\end{array}$ & $\stackrel{\cong}{I}$ & 哭 & $\stackrel{8}{\circ}$ & $\stackrel{ \pm}{2}$ & in & 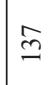 \\
\hline$\cdot \tilde{z}$ & $\stackrel{0}{2}$ & ळ & $\tilde{I}$ & ๑ & 灾 & $\stackrel{\infty}{\Xi}$ & $\dddot{n}$ & in & $\vec{\infty}$ & $\cong$ & $\stackrel{0}{0}$ & $\stackrel{\infty}{\sim}$ & 昌 & $\stackrel{\infty}{\infty}$ & ڤે & $\cong$ & $\underline{n}$ & 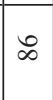 & है \\
\hline 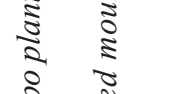 & 3 & $\vec{\nabla}$ & 언 & ᄋे & $\stackrel{n}{\sim}$ & $\widetilde{\Xi}$ & 甼 & $\infty$ & $\bar{\Xi}$ & $\stackrel{\beth}{I}$ & $\underset{\Phi}{ \pm}$ & 守 & $\underline{n}$ & ¿ & 6 & $\stackrel{\infty}{\infty}$ & $\Xi$ & $\cong$ & $\tilde{\Omega}$ \\
\hline 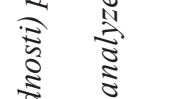 & Z & $\frac{n}{v}$ & 五 & \& & $\stackrel{m}{\sim}$ & $\infty$ & I & $\bar{\Xi}$ & $\infty$ & $\stackrel{n}{=}$ & $\mathscr{\infty}$ & $\stackrel{0}{ \pm}$ & $n$ & $\hat{\Omega}$ & ț & 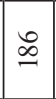 & $E$ & $\cong$ & $\vec{n}$ \\
\hline - & $\sum$ & $\stackrel{\sim}{\sim}$ & \begin{tabular}{l}
0 \\
\hdashline
\end{tabular} & ¿̊ & $\stackrel{\circ}{\sim}$ & ఏ & 寻 & $\stackrel{\infty}{\subseteq}$ & $\stackrel{\infty}{\infty}$ & $\stackrel{\infty}{=}$ & 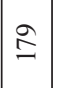 & 年 & $\stackrel{\curvearrowleft}{\curvearrowleft}$ & $\hat{\Omega}$ & 6 & $\Phi$ & 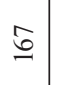 & 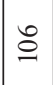 & $\stackrel{+}{\check{t}}$ \\
\hline z & 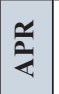 & $\underset{\infty}{\infty}$ & $\Xi$ & $\stackrel{0}{I}$ & $\underline{\sigma}$ & $\stackrel{\circ}{\circ}$ & 인 & $\stackrel{I}{ \pm}$ & 5 & $\widetilde{\sigma}$ & กี & ปे & ले & $\stackrel{\infty}{=}$ & $\vec{n}$ & 3 & 哭 & 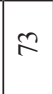 & $\Xi$ \\
\hline 0 & $\stackrel{\nwarrow}{\Sigma}$ & $\underline{6}$ & ๙ & 6 & $\hat{n}$ & in & ชิ & $\overrightarrow{\mathrm{I}}$ & 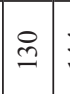 & 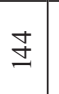 & 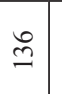 & $\stackrel{1}{\beth}$ & $\stackrel{m}{=}$ & $\underset{0}{\infty}$ & ले & $\stackrel{n}{n}$ & $\widehat{\beth}$ & 芯 & $\bar{m}$ \\
\hline $\begin{array}{l}0 \\
2\end{array}$ & 禹 & 同 & 咅 & $\stackrel{\varrho}{=}$ & $\stackrel{n}{\varrho}$ & $\widehat{\beth}$ & 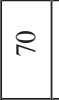 & I & $\stackrel{\infty}{\circ}$ & $\Xi$ & $\stackrel{8}{ }$ & 2 & 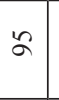 & $\overline{\underline{m}}$ & a & $\vec{\beth}$ & à & $\simeq$ & à \\
\hline 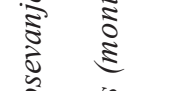 & Z & $\stackrel{\infty}{=}$ & 8 & 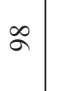 & $\stackrel{\Xi}{\Xi}$ & 익 & $\overline{6}$ & $\approx$ & $a$ & $\approx$ & $\bar{a}$ & $\infty$ & $\infty$ & $\stackrel{\infty}{\underset{工}{\sim}}$ & $\bar{a}$ & $\Xi$ & สু & 0 & $\infty$ \\
\hline 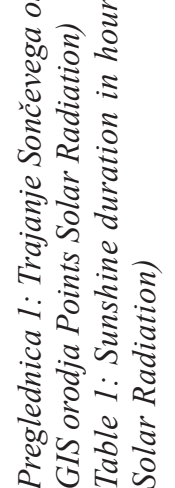 & 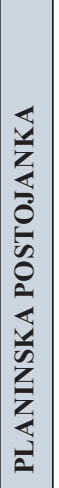 & 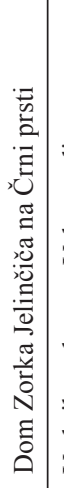 & 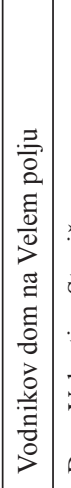 & 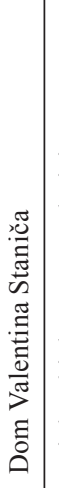 & 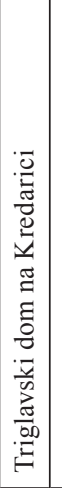 & 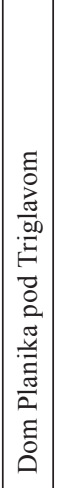 & 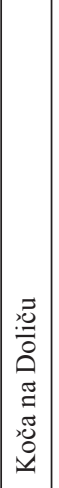 & 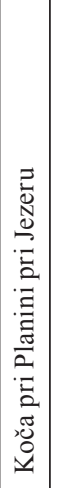 & 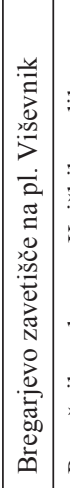 & 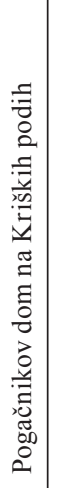 & 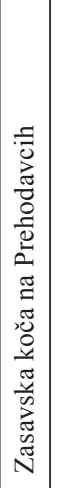 & 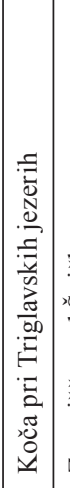 & 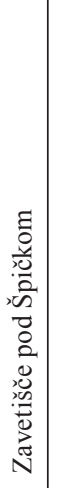 & 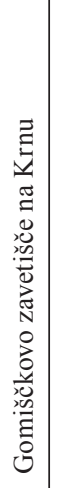 & 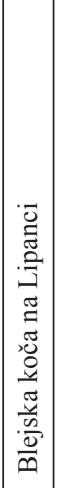 & 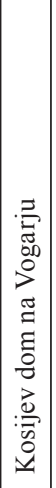 & 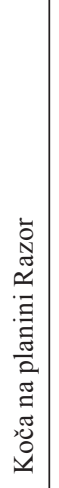 & 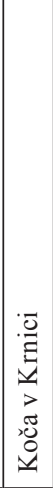 & 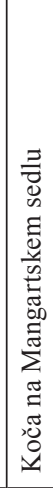 \\
\hline
\end{tabular}


Slika 2: Viri električne energije na planinskih postojankah v letih 1992, 1999 in 2012

Figure 2: Electricity supply for mountain huts in 1992, 1999 and 2012

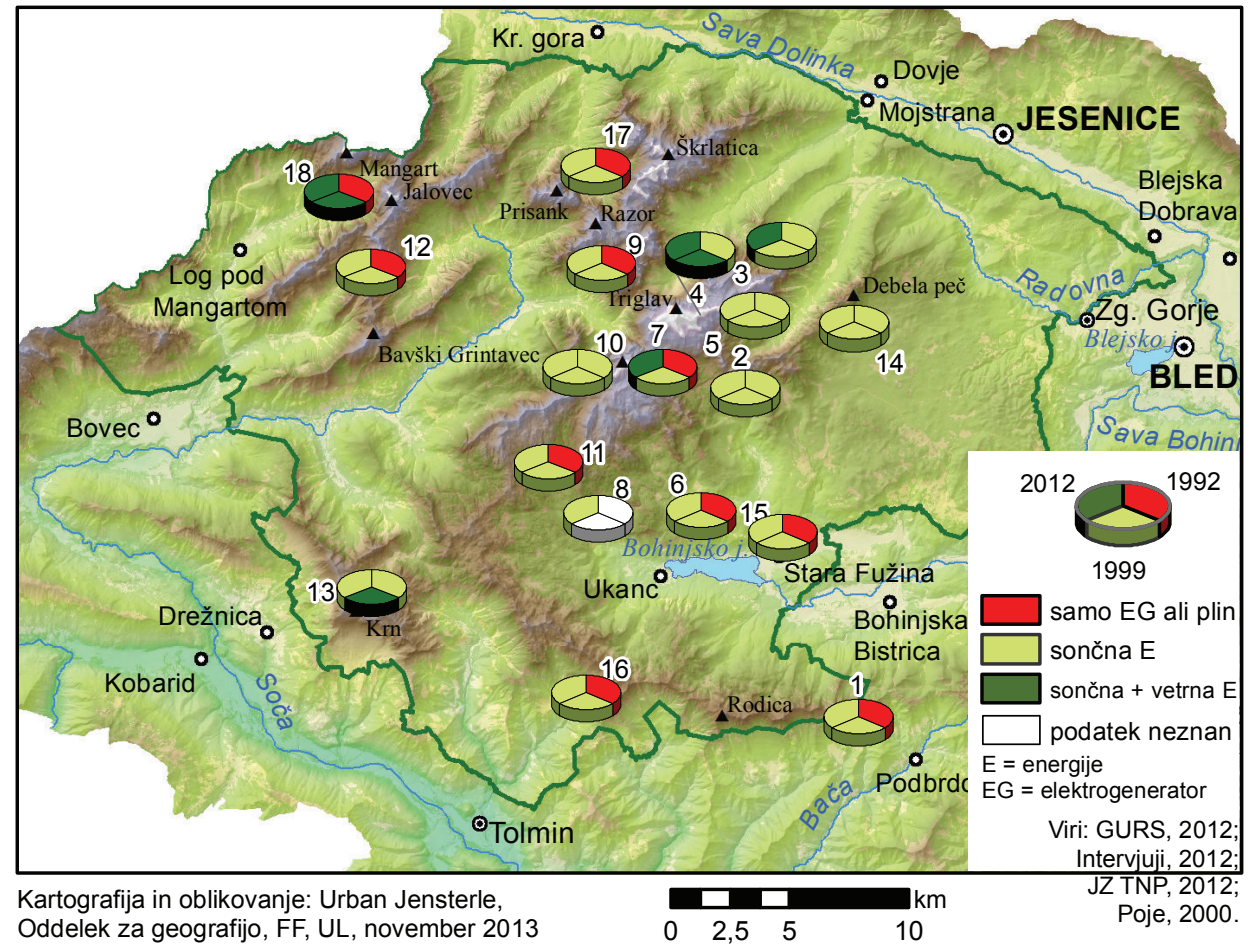

Električni generatorji so bili v poletju 2012 z izjemo Koče na Mangartskem sedlu prisotni na vseh preučevanih postojankah. Na več kot polovici so električne generatorje označili kot rezervni vir energije v primerih dolgotrajnejšega oblačnega vremena ali večjih gradbenih del. Vodnikov dom na Velem polju je v mesecu avgustu 2012 za pokritje potreb po električni energiji med vsemi analiziranimi postojankami uporabljal električni generator največ - kar 6 ur dnevno. Velik delež je odpadel na jutranje ure, saj zaradi Tosca prvi žarki obsijejo dom šele ob deseti uri. Koča na Planini pri Jezeru uporablja električno energijo iz generatorja za jutranje in večerno črpanje vode iz jezera in pogon čistilne naprave. Podobno tudi Koča pri Triglavskih jezerih kot pomemben razlog za urno ali dvourno delovanje električnega generatorja dnevno navaja porabo čistilne naprave. Triglavski dom na Kredarici uporablja električni generator v avgustu približno štiri ure dnevno (Poje, 2000; Intervjuji, 2012). Omenjeni dom je ravno v avgustu najmanj samooskrben z električno energijo iz obnovljivih virov, saj kar 65 \% električne energije pridobijo iz fosilnih goriv (Čeh, 2013). Triglavski dom ima med vsemi analiziranimi postojankami tudi največjo letno porabo goriva za generator - v zadnjih sezonah so porabili približno 3000 l nafte za potrebe planinskega doma, dodatnih 30001 pa za nemoteno delovanje meteorološke postaje. V letu 2013 so prešli na nov energent, in sicer na zemeljski plin (Poje, 2000; Intervjuji, 2012). 
Slika 3: Dnevna uporaba električnih generatorjev (v urah) v planinskih postojankah v letu 2012 Figure 3: Daily use of electric generators (in hours) in mountain huts in 2012
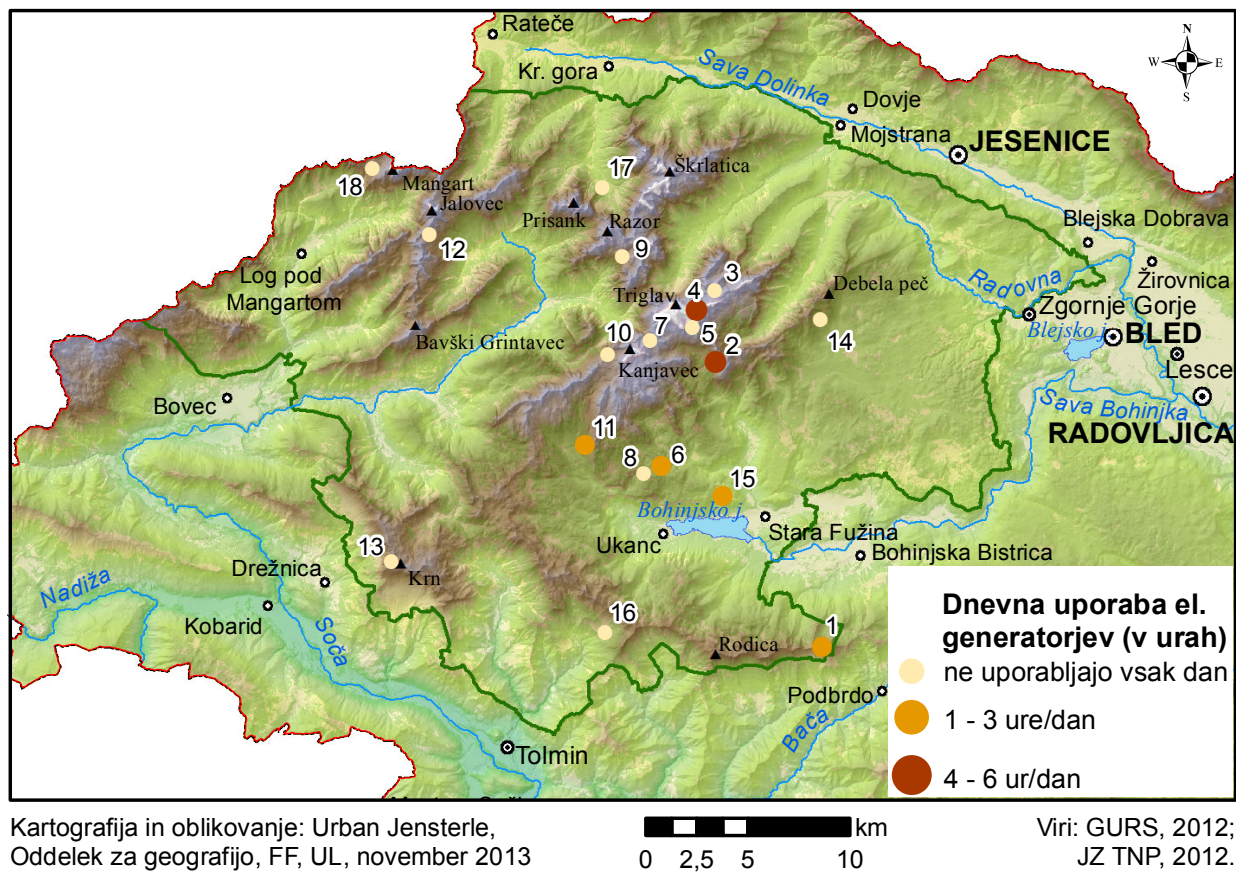

Viri: GURS, 2012;

JZ TNP, 2012.

\section{TIPIZACIJA PLANINSKIH POSTOJANK NA PODLAGI ENERGETSKIH ZNAČILNOSTI}

Analiza planinskih postojank v TNP z vidika energetske oskrbe je bila sestavljena iz treh delov, in sicer potreb po energiji, oskrbe z električno energijo in oskrbe s toplotno energijo. Tipizacija je bila narejena na podlagi devetih lastnosti. Vsaka je imela enako težo, torej devetino skupne teže. Vrednost vsake lastnosti za posamezno postojanko je bila med 0 in 1 . Kategorizirane vrednosti lastnosti smo določili na podlagi podatkov iz terenskega popisa v poletju 2012 - kako so bile vrednosti določene, nam pojasnijo opombe pod preglednico 2. Na osnovi seštevka vseh vrednosti smo planinske postojanke razdelili v štiri skupine. Kategorizacijo prikazuje preglednica 2, geografsko razporeditev tipov slika 4 . 


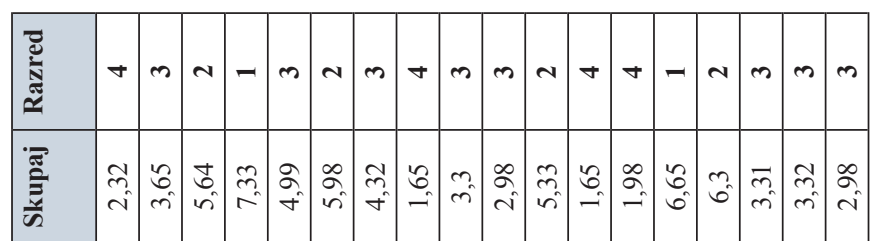

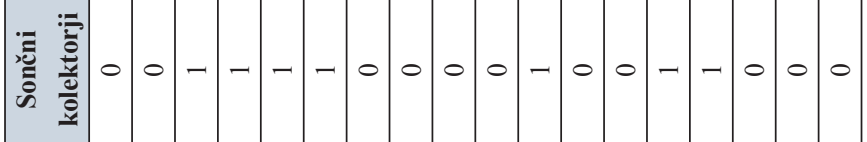$$
\text { 竞 }
$$

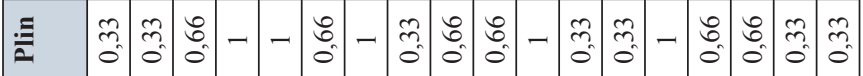

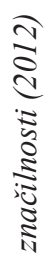

\begin{tabular}{|c|c|c|c|c|c|c|c|c|c|c|c|c|c|c|c|c|c|}
\hline$\stackrel{\pi}{\underline{b}}$ & - & - & $\begin{array}{l}8 \\
0 \\
0\end{array}$ & $\begin{array}{c}\tilde{2} \\
0\end{array}$ & $\begin{array}{c}m \\
\text { ?. }\end{array}$ & 0 & -1 & $\begin{array}{c}m \\
0\end{array}$ & $\begin{array}{l}: \\
: \\
0\end{array}$ & 0 & 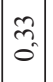 & लि & $\stackrel{8}{0}$ & & $\begin{array}{l}\mathbb{R}^{\circ} \\
:\end{array}$ & $\begin{array}{l}: \\
: \\
0\end{array}$ & - \\
\hline
\end{tabular}

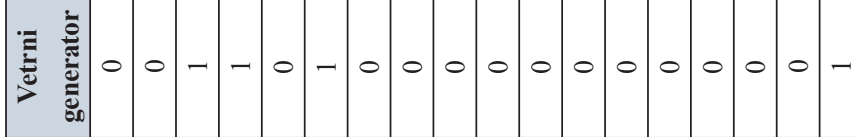

$\therefore$

के ฮิ

20

इิ

कo

है क्षे

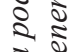

$\stackrel{2}{2} 0$

\$

$\therefore$

¿

졸

इิ

혼

:

공

. 5

स्ते के

$\ddot{i} \stackrel{0}{0}$

के

$\stackrel{5}{2}$

$\frac{0}{0} \div$

ए।

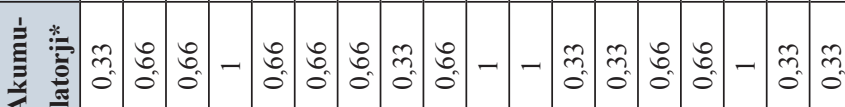

$$
\text { 竞 }
$$

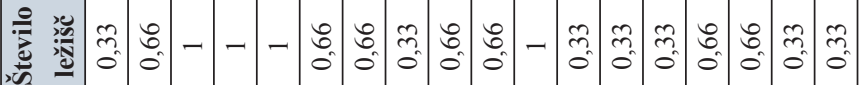

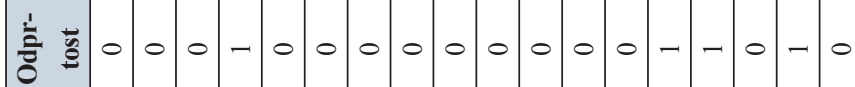

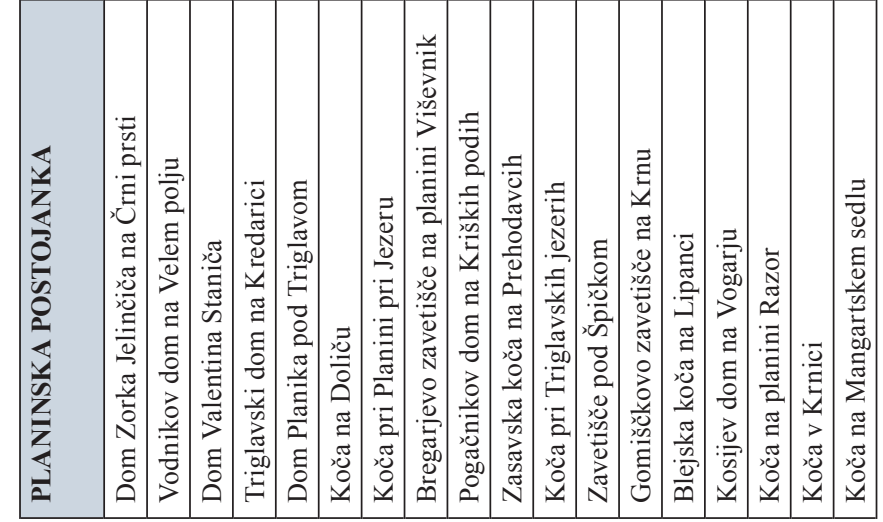

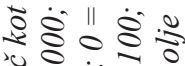

的范。

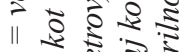

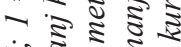

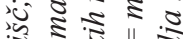
गू 11 ई $m$ ह

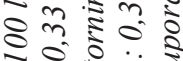
I $\because$ 苛

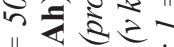
는 20.5 $0: \overline{0}$ N ये ज्ञ है है

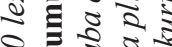
น पर $-\dot{0} 10$

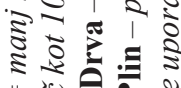
II 4 a

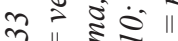
2. 11 . $\approx 0$ 获向得 에는 bi

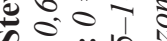
的苛 $n$ ¿

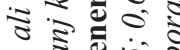

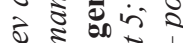
ชั

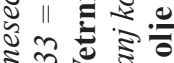
₹ $2>$ $\|\ddot{\bar{S}}\|$ -

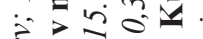
वे $\approx 01$

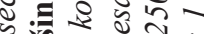

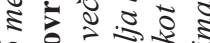

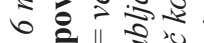
$\therefore$ 인 ¿ 2.0

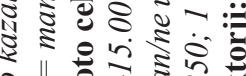
201 0 성 :

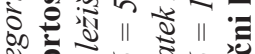

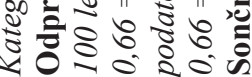


Preglednica 3: Tipi planinskih postojank na podlagi energetskih značilnosti (2012) Table 3: Types of mountain huts according to energy supply (2012)

\begin{tabular}{|l|r|r|l|c|}
\hline Razred & \multicolumn{1}{|l|}{ Od } & \multicolumn{1}{l|}{ Do } & Tip & Število postojank \\
\hline $\mathbf{4}$ & & $<2,5$ & majhen porabnik energije & 4 \\
\hline $\mathbf{3}$ & $>=2,5$ & $<5$ & srednji porabnik energije & 8 \\
\hline $\mathbf{2}$ & $>=5$ & $<6,5$ & velik porabnik energije & 4 \\
\hline $\mathbf{1}$ & $>=6,5$ & & največji porabnik energije & 2 \\
\hline
\end{tabular}

Opomba: Mejne vrednosti so iz preglednice 2.

Slika 4: Tipi planinskih postojank na podlagi energetskih značilnosti v letu 2012

Figure 4: Types of mountain huts by level of energy consumption in 2012

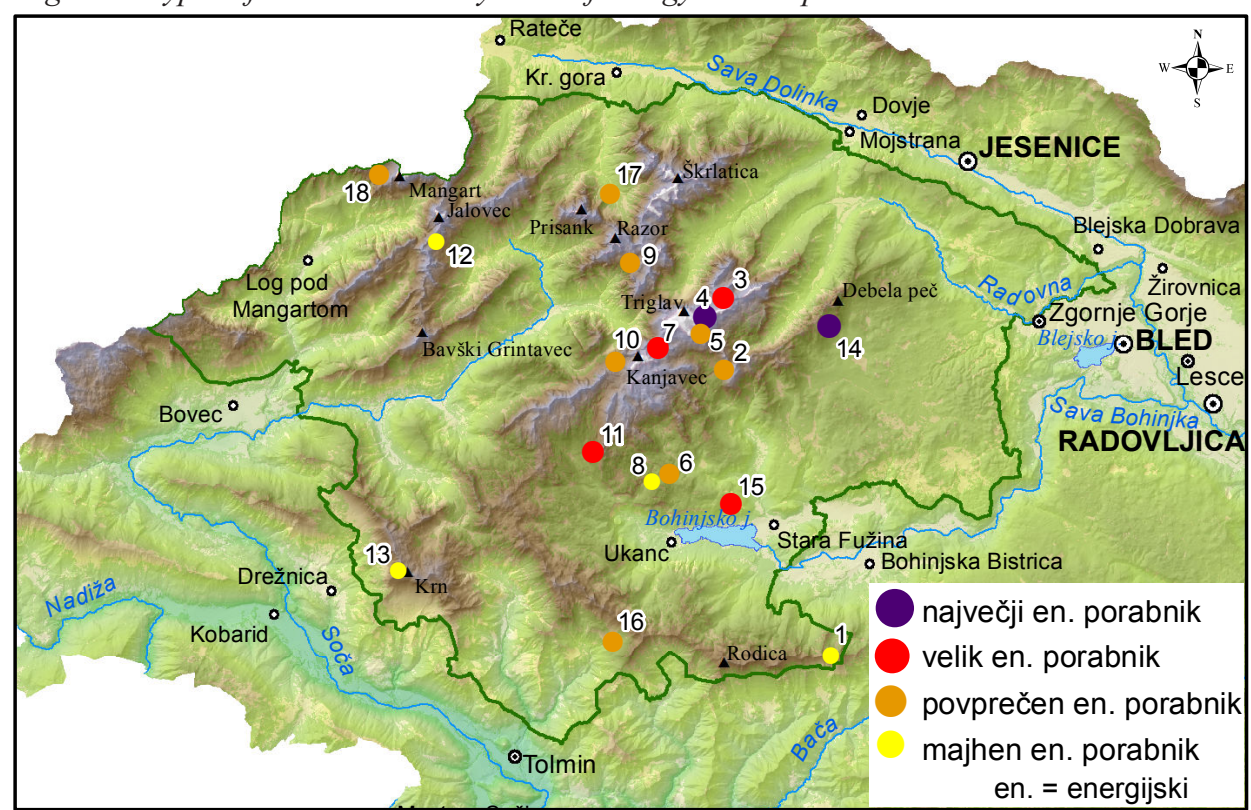

Kartografija in oblikovanje: Urban Jensterle,

Oddelek za geografijo, FF, UL, november 2013

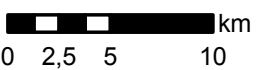

Viri: GURS, 2012; JZ TNP, 2012.

Med majhne porabnike energije spadajo Dom Zorka Jelinčiča na Črni prsti in vsa tri analizirana zavetišča: Bregarjevo zavetišče na planini Viševnik, Gomiščkovo zavetišče na Krnu in Zavetišče pod Špičkom. Slaba polovica (8) preučevanih postojank spada V kategorijo povprečnih porabnikov energije. Veliki porabniki so štirje, in sicer Dom Valentina Staniča, Koča na Doliču, Koča pri Triglavskih jezerih in Kosijev dom na Vogarju. V kategorijo največjih porabnikov spadata množično obiskan Triglavski dom na Kredarici in celo leto odprta Blejska koča na Lipanci. 


\section{SAMOZADOSTNOST PLANINSKIH POSTOJANK Z ELEKTRIČNO ENERGIJO IZ OBNOVLJIVIH VIROV}

Rezultati kažejo, da sta dve tretjini planinskih postojank avgusta 2012 pokrili vse potrebe po električni energiji iz obnovljivih virov. Analiza je tudi potrdila, da je samozadostnost praviloma problem večjih, bolj obiskanih in dalj časa odprtih planinskih postojank. Manjše, a ne nujno tudi manj obiskane postojanke, se praviloma uspešno oskrbujejo z električno energijo zgolj s pretvorbo sončne energije. Razlog je predvsem v drugačni strukturi porabnikov elektrike v primerjavi z večjimi postojankami. Zavetišča na primer ne uporabljajo elektrike za hladilne naprave - Bregarjevo zavetišče na planini Viševnik v sezoni 2012 sploh ni imelo hladilnih naprav, Gomiščkovo zavetišče na Krnu je kot naravno hladilnico uporabljalo kaverno, Zavetišče pod Špičkom pa je imelo manjši kombinirani hladilnik na plin. Drugih, z električno energijo še bolj potratnih naprav niso imeli, tako da je bila osvetlitev največji ali celo edini porabnik elektrike, za to pa je praviloma dovolj nekaj kvadratnih metrov sončnih celic. Tudi večje postojanke, ki so imele praviloma vsaj hladilnik in zamrzovalnik, se $\mathrm{v}$ večji meri uspešno preskrbujejo z električno energijo zgolj z rabo obnovljivih virov energije (Intervjuji, 2012).

Slika 5: Energetska samozadostnost planinskih postojank v letu 2012

Figure 5: Mountain huts by self-sufficiency of electricity supply in 2012

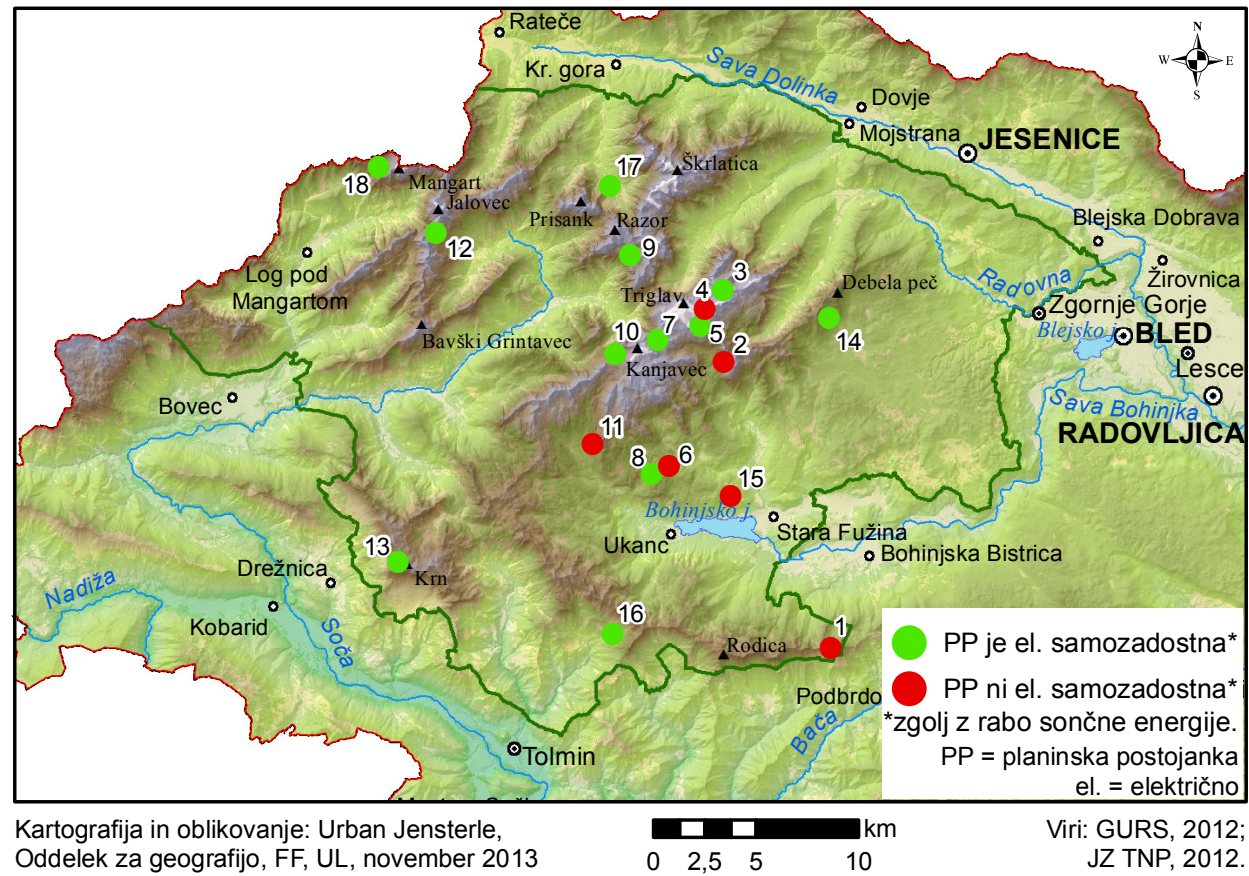


Med planinskimi postojankami, ki se v avgustu 2012 niso bile sposobne oskrbovati z elektriko zgolj s pretvorbo sončne in vetrne energije, so praviloma največje in dalj časa odprte. Te so imele v sezoni 2012 poleg hladilnih naprav in osvetlitve še številne druge, energijsko potrošne porabnike električne energije, npr. električne peči za kruh, čistilne naprave, vodne črpalke itd.

\section{PREDLOGI ZA ENERGETSKO SAMOZADOSTNOST PLANINSKIH POSTOJANK}

V predlogih za doseganje samozadostnosti šestih postojank z električno energijo iz obnovljivih virov navajamo konkretne in izvedljive rešitve. Za vsako smo izpostavili prioritetne naloge, medtem ko nekaj glavnih smernic velja za vse. Prva zajema varčnejšo uporabo električnih naprav; pri osvetljavi izpostavljamo namestitev senzorjev gibanja in časovnih stikalnih ur, pri hladilnih napravah pa nastavitev na najvišjo sprejemljivo temperaturo hlajenja. Druga smernica izpostavlja zmanjšano porabo električne energije za ogrevanje vode $\mathrm{z}$ namestitvijo sončnih kolektorjev. Za potrebe osebne higiene nekajčlanskega osebja praviloma zadošča že nekaj kvadratnih metrov sončnih kolektorjev (Intervjuji, 2012). Tretja smernica predlaga odstranitev energijsko potrošnih hladilnih naprav za pijače in njihovo hlajenje v kletnih prostorih. Planinske postojanke, ki imajo na voljo zadostne količine vode, lahko pijače hladijo v sodih vode. Četrta smernica predlaga zamenjavo energijsko potrošnih svetil in hladilnih naprav za energijsko varčnejše izvedbe. Svetleče diode porabijo 80 \% manj energije kot navadne žarnice (Energetika ..., 2013). Ravno tako velja, da hladilna naprava energijskega razreda $\mathrm{A}+++\mathrm{v}$ primerjavi z razredom D porabi le petino energije (Nova EU energijska nalepka, 2013). Predlagamo tudi posodobitve fotovoltaičnega sistema, kar vključuje tako posodobitev sončnih celic in fotonapetostnega sistema kot tudi povečanje zmogljivosti baterij.

\section{I. Dom Zorka Jelinčiča na Črni prsti}

Dom je bil do pred nekaj sezonami pri oskrbi z električno energijo samozadosten zgolj s pretvorbo sončne energije. Hladilnik je deloval na plin, električni generator so uporabljali predvsem za ogrevanje vode za potrebe osebja. Zaradi povečanega obiska so namestili dodaten kombinirani hladilnik energijskega razreda A. Potrebe po električni energiji so se tako povečale, oskrbo pa je osiromašila strela, ki je deloma uničila fotovoltaični sistem. Hladilnik na plin je prenehal pravilno delovati, a ga zaradi pomanjkanja električne energije niso mogli priklopiti na električni sistem in so ga bili primorani odstraniti. V poletju 2012 sta bila največja porabnika električne energije kombinirana hladilna naprava in osvetljava, precejšen delež je odpadel tudi na grelec vode. V sončnem vremenu je električni generator deloval uro do dve dnevno, drugače dlje (Intervjuji, 2012). 


\section{Predlogi za učinkovitejšo oskrbo z električno energijo:}

- zamenjava kombiniranega hladilnika z energijsko varčnejšo izvedbo;

- zamenjava neonskih žarnic za LED svetila;

- namestitev novih sončnih celic in

- namestitev dodatnih kapacitet baterij, saj sončni potencial omogoča nadgradnjo fotovoltaičnega sistema.

Prednostna naloga: nadgradnja fotovoltaičnega sistema.

\subsection{Vodnikov dom na Velem polju}

Dom je imel v sezoni 2012 hladilne naprave energijskega razreda A, vse žarnice so bile varčne (Intervjuji, 2012). Pretvorba sončne energije v električno je bila okrnjena zaradi sence Tosca, saj Sonce avgusta dom prvič obsije šele ob deseti uri.

\section{Predlogi za učinkovitejšo oskrbo z električno energijo:}

- namestitev nekaj kvadratnih metrov sončnih kolektorjev namesto gretja vode z električno energijo;

- odstranitev potrošnih hladilnih naprav za pijače in njihovo hlajenje na druge načine. V bližini doma je npr. vodni izvir, ki bi omogočal hlajenje pijač v sodih vode;

- ukrepi na fotovoltaičnem sistemu: usmeritev in naklonski kot strešine objekta ob domu sta ugodna za postavitev dodatnih sončnih celic. Več energije bi lahko shranili, če bi povečali zmogljivosti baterij.

Prednostna naloga: nadgradnja fotovoltaičnega sistema, predvsem povečanje zmogljivosti baterij.

\subsection{Triglavski dom na Kredarici}

Dom je v določenih delih leta samozadosten z električno energijo zgolj z rabo sončne in vetrne energije. Najslabše se dom pri oskrbi izkaže v avgustu - v avgustu 2012 so kar dve tretjini električne energije pridobili z električnim generatorjem iz fosilnih goriv. Iz sončne energije so pridobili $20 \%$, iz vetrne pa $14 \%$ električne energije (Čeh, 2013). V poletju 2012 so imeli v domu dva velika hladilnika za pijačo, tri zamrzovalnike, pralni stroj, električno peč za kruh, električno napravo za mesenje kruha, električno stiskalnico za smeti, grelnike vode, črpalko za vodo izpod Triglavskega ledenika, okoli 300 žarnic itd. (Intervjuji, 2012). Celoten energetski koncept je zapleten zaradi dvojne oskrbe (planinski dom in meteorološka postaja). Del sončnih celic je namenjen planincem in nemotenemu delovanju postojanke, drugi del zagotavlja nemoteno delovanje meteorološke postaje. Vsa proizvedena električna energija se shranjuje v skupnih baterijah (Čeh, 2013).

\section{Predlogi za učinkovitejšo oskrbo z električno energijo:}

- odstranitev hladilnih naprav za pijačo, saj kletni prostori na nadmorski višini $2515 \mathrm{~m}$ zadoščajo za hlajenje pijače na sprejemljivo temperaturo; 
- Študija o smiselnosti postavitve dodatne vetrnice, saj obstoječa v primerjavi s sončnimi celicami pomembno prispeva k oskrbi z električno energijo.

Prednostna naloga: študija o smiselnosti postavitve dodatne vetrnice.

\subsection{Koča na Planini pri Jezeru}

V planinski postojanki so v sezoni 2012 uporabljali hladilnik, hladilno omaro, hladilno omaro za pijačo in zamrzovalno skrinjo energijskega razreda A. Prav tako so imeli grelnik vode, dve manjši in dve večji vodni črpalki, čistilno napravo in 40 varčnih žarnic (Intervjuji, 2012). V naših predlogih so zajeti ukrepi glede hladilnih naprav in osvetljave, ukrepov glede energijsko potrošnih vodnih črpalk in elektromotorja čistilne naprave nismo predvideli, predlagamo pa, da se ob njihovi zamenjavi veliko pozornost nameni energijski učinkovitosti.

\section{Predlogi za učinkovitejšo oskrbo z električno energijo:}

- namesto gretja vode $\mathrm{z}$ električno energijo $\mathrm{v}$ grelnikih vode namestitev nekaj kvadratnih metrov sončnih kolektorjev;

- gostinska hladilna omara je največji porabnik elektrike v planinskih postojankah. Zaradi tega je priključena le občasno in dela največ 10 ur dnevno (Intervjuji, 2012). Z odstranitvijo hladilne omare bi samo v avgustu privarčevali približno $52 \mathrm{kWh}$ (lasten izračun);

- z zamenjavo ostalih hladilnih naprav za energijsko varčnejše izvedbe podobnih dimenzij bi samo v avgustu privarčevali dobrih $25 \mathrm{kWh}$ (lasten izračun);

- z zamenjavo varčnih žarnic za LED svetila bi samo v avgustu privarčevali dodatnih 28 kWh (lasten izračun);

- na strešini objekta ob koči je 24 kvadratnih metrov sončnih celic. Strešina je z vidika usmeritve in naklonskega kota glede na poletni hod Sonca zelo ugodna, a že popolnoma zasedena. Sleme planinske koče je v smeri sever-jug (Jensterle, 2013). Namestitev dodatnih sončnih celic bi bila zaradi izkoristka smiselna samo pod kotom, kar pa je v navzkrižju z usmeritvami TNP, saj morajo biti fotovoltaični moduli zaradi upoštevanja krajevnih stavbarskih značilnosti umeščeni v ravnino strešin (Zakotnik, 2012). Ob nadgraditvi vršne moči sončnih celic bi bila smiselna tudi nadgradnja zmogljivosti baterij.

Prednostna naloga: zamenjava električnih naprav za energijsko varčnejše izvedbe - odstranitev hladilne omare za pijačo, z zamenjavo hladilnih naprav in žarnic za varčnejše izvedbe bi samo v avgustu privarčevali 105 kWh električne energije (lasten izračun).

\subsection{Koča pri Triglavskih jezerih}

V sezoni 2012 so v planinski postojanki uporabljali tri hladilne omare za pijačo, zamrzovalnik, nekaj manjših električnih naprav (npr. salamoreznica in mešalnik), pralni stroj, čistilno napravo in 70 žarnic, od tega 50 varčnih in 20 klasičnih (Intervjuji, 2012). Med predlogi nismo predvideli namestitve varčnejšega elektromotorja čistilne naprave, saj je 
zamenjava velik finančni zalogaj. Energijska učinkovitost naj se upošteva ob celoviti prenovi ali zamenjavi čistilne naprave.

\section{Predlogi za učinkovitejšo oskrbo z električno energijo:}

- z odstranitvijo potrošnih hladilnih omar za pijačo bi mesečno privarčevali $44 \mathrm{kWh}$ (lasten izračun). Pijače bi lahko hladili v kletnih prostorih, dodatno pa še v sodih vode, saj te zaradi bližnjega potoka ne primanjkuje;

- z zamenjavo zamrzovalnika za energijsko najvarčnejšo izvedbo istih dimenzij bi v avgustu privarčevali slabih $20 \mathrm{kWh}$ (lasten izračun);

- $\quad$ z zamenjavo sedanjih žarnic z LED svetili bi v avgustu privarčevali $161 \mathrm{kWh}$ (lasten izračun);

- namestitev dodatnih sončnih celic, obrnjenih proti jugu, je zaradi usmerjenosti strešnega slemena sever-jug omejena. Možna bi bila namestitev dodatnih sončnih celic na strešinah, obrnjenih proti vzhodu in zahodu, zavedajoč se zmanjšanega učinka pretvorbe v primerjavi z južno ekspozicijo.

Prednostna naloga: zamenjava električnih naprav za varčnejše izvedbe in odstranitev hladilnih naprav za pijače. S temi ukrepi (brez zamenjave elektromotorja čistilne naprave) bi v avgustu privarčevali $225 \mathrm{kWh}$ (lasten izračun).

\subsection{Kosijev dom na Vogarju}

Za nemoteno oskrbo z električno energijo uporabljajo električni generator dve do tri ure dnevno. Delež fosilnih goriv pri njenem pridobivanju je približno enakovreden doprinosu sončne energije. Planinsko društvo Železničar Ljubljana išče v zadnjih sezonah rešitve za opustitev ali vsaj izrazito zmanjšanje porabe fosilnih goriv, pri čemer se odločajo med dvema povsem različnima pristopoma. Nagibajo se k priklopu na javno električno omrežje, kar pa je velik finančni zalogaj. Na drugi strani se zavedajo sončnega potenciala in ugodnih lastnosti južne strešine objekta (Intervjuji, 2012). Dom je imel v sezoni 2012 pet sob s kopalnicami. V primeru priključitve na električno omrežje predvidevamo, da bi se postojanka sčasoma iz pohodniškega turizma preusmerila v klasičnega.

\section{Predlogi za učinkovitejšo oskrbo z električno energijo:}

- z odstranitvijo hladilnih naprav za pijače in hlajenje teh v sodih vode bi samo v avgustu privarčevali več kot 100 kWh električne energije (lasten izračun). Dom je priključen na skupinski vodovod, ki ima urejeno zajetje pod Pršivcem (Intervjuji, 2012) in jim tako vode ne primanjkuje;

- prednostno shranjevanje živil v zamrzovalniku energijskega razreda $\mathrm{A}+++$ in občasen izklop zamrzovalnika energijskega razreda $\mathrm{B}$, če bi razmere to dopuščale;

- naklonski kot južne strešine doma omogoča največje izkoristke sončne energije. Na voljo je še veliko prostora za namestitev dodatnih sončnih celic. Sočasno je potrebna tudi nadgradnja zmogljivosti baterij. Ugodna je tudi topoklimatska lega - dom stoji na južnem pobočju, nad inverzno plastjo.

Prednostna naloga: nadgradnja celotnega fotovoltaičnega sistema. 


\section{SKLEP}

Julijske Alpe že dve stoletji privabljajo raziskovalce, pohodnike in gornike. Planinske postojanke so z nudenjem zavetja, prenočišča, hrane in pijače postale nepogrešljiv del pohodništva in gorništva. Ravno gorniki so bili prvi, ki so se začeli zavedati negativnih vplivov človeka na ranljivo visokogorsko okolje in dali prve pobude za ustanovitev danes edinega narodnega parka v Sloveniji - Triglavskega narodnega parka (TNP). V zadnjih letih TNP in še posebej PZS vse bolj odločno omejujeta vplive človeka na okolje in naravo.

Analiza podatkov, pridobljenih na terenu poleti 2012, kaže, da imajo obnovljivi viri energije vse pomembnejšo vlogo pri proizvodnji električne energije za potrebe planinskih postojank. Vse preučevane postojanke so imele v omenjenem obdobju nameščene sončne celice, štiri dodatno tudi vetrne generatorje, medtem ko kraško površje praviloma ne omogoča rabe vodne energije, saj vode odtekajo podzemno. Potrjena je bila tudi teza, da imajo postojanke večji sončni potencial, kot so ga v poletju 2012 uspele izkoristiti. Poudariti velja tudi velike rezerve v vetrni energiji. Ravno tako spodbudne so ugotovitve o zmanjšani vlogi električnih generatorjev pri oskrbi z električno energijo. Več kot polovica planinskih postojank je električni generator označila kot rezerven vir energije, letno porabo pa kot minimalno, marsikatero leto nično.

Za šest planinskih postojank, ki v avgustu 2012 niso bile samozadostne pri oskrbi z električno energijo zgolj iz obnovljivih virov energije, smo predlagali realne in v nekaterih primerih lahko izvedljive rešitve. Fotovoltaični sistem Doma Zorka Jelinčiča na Črni prsti je poškodovala strela. Naložba v obnovo ali nadgradnjo omenjenega sistema je zaradi velikega sončnega potenciala prednostna naloga. Podobno nalogo, predvsem s povečanjem zmogljivosti baterij, smo predlagali tudi za Vodnikov dom na Velem polju. Triglavski dom na Kredarici je v določenih delih leta samozadosten z električno energijo iz obnovljivih virov energije, kar za avgust ne velja. Rezerve v proizvodnji električne energije iz obnovljivih virov so v vetrni energiji. Kočama na Planini pri Jezeru in pri Triglavskih jezerih je skupna velika poraba električne energije za delovanje različnih naprav. Odstranitev potrošnih hladilnih naprav za pijače ter zamenjava hladilnih naprav in svetil za varčnejše izvedbe bi morala biti prednostna naloga. Planinskemu društvu Železničar Ljubljana na podlagi izračunov trajanja Sončevega obsevanja in primernih južnih strešin Kosijevega doma na Vogarju svetujemo naložbo v fotovoltaični sistem.

Podrobna analiza kaže zadosten potencial za oskrbo z električno energijo zgolj iz obnovljivih virov energije. Prehod iz fosilnih goriv na obnovljive vire naj spodbudi tudi skrb za ranljivo visokogorsko kraško okolje. Uporaba fosilnih goriv predstavlja poleg onesnaževanja ozračja s produkti zgorevanja tudi nevarnost onesnaženja vodnih virov v primeru razlitja.

\section{Viri in literatura}

Čeh, J., 2013. Osnove fotovoltaičnih sistemov in oskrba Triglavskega doma na Kredarici z električno energijo (osebni vir, 29. 1. 2013). Ljubljana.

Deubler, H., Hubmann, J., Höfler, H., Niederberger, T., Steinbacher, G., 2011. Smernice za okolju primerno tehniko na planinskih kočah: načrtovanje, izgradnja, obratovanje, vzdrževanje. Ljubljana, Planinska zveza Slovenije, 128 str. 
Dretnik, D., 2012. Projekt Dodelitev znaka »Okolju prijazna koča«. URL: http://www. pzs.si/javno/dokumenti/gk\%20pzs/GK_PZS-Projekt-Znak-OPK_in_vprasalnik2012. pdf (Citirano 26. 5. 2012).

Energetika. Energijsko varčna svetila, 2013. URL: http://ec.europa.eu/energy/lumen/ overview/whatchanges/index_sl.htm (Citirano 1. 6. 2013).

Intervjuji, 2012. (R. Balažič, S. Elmazović, F. Erlah, A. Jenko, T. Štekler, M. Trojar, H. Uranič, T. Vodopivec, I. Voler in drugi) Energetska oskrba planinskih postojank V Triglavskem narodnem parku (osebni viri, avgust 2012).

Jensterle, U., 2013. Geografska analiza energetske oskrbe in potenciala za rabo sončne energije na planinskih postojankah Triglavskega narodnega parka. Diplomsko delo. Ljubljana, Filozofska fakulteta, Oddelek za geografijo, 131 str.

Menz, V., 2008. Umwelttechnik für alpine Berg- und Schutzhütten: Hintergrundwissen, Tipps und Beispiele aus der Praxis. 1. izdaja. Müchen, Bergverlag Rother GmbH, 294 str.

Nova EU energijska nalepka, 2013. URL: http://www.newenergylabel.com/si/discover_ the label (Citirano 1.6.2013).

Plut, D., 2004. Geografske metode proučevanja degradacije okolja. Ljubljana, Filozofska fakulteta, Oddelek za geografijo, 188 str.

Poje, J., 2000: Stanje okolja v Triglavskem narodnem parku z vidika rabe energije. Diplomsko delo. Ljubljana, Fakulteta za strojništvo, 107 str.

Seznam koč, zavetišč in bivakov. Julijske Alpe. Planinska zveza Slovenije, 2013. URL: http://www.pzs.si/koce.php?reg=3 (Citirano 26. 5. 2013).

Šarkezi, M., 2013. Posvet z generalnim sekretarjem Alpske konvencije na MOP.

URL: http://www.pzs.si/novice.php?pid=4774 (Citirano 26. 5. 2013).

Predstavitev. Planinska zveza Slovenije, 2013. URL: http://www.pzs.si/vsebina.php?pid=1 (Citirano 26. 5. 2013).

Triglavski narodni park,, 2013. URL: http://www.tnp.si/spoznavati/C4/ (Citirano 26. 5. 2013). Zakotnik, I., 2012. Energetska oskrba planinskih postojank Triglavskega narodnega parka (osebni vir, 11. 4. 2013). Bled.

\section{ENERGY SELF-SUFFICIENCY OF MOUNTAIN HUTS INTRIGLAV NATIONAL PARK}

\section{Summary}

Julian Alps attract researchers, hikers and mountaineers for two centuries. Mountain huts have become indispensable part of mountaineering activities by offering shelter, accommodation, food and drinks. The mountaineers were the first to point out the negative impact of human activities on fragile mountain karst environment and gave first initiative for establishing the Triglav National Park, the only national park in Slovenia. Many actions and programs have been carried out in last years to reduce the impact on nature and environment. Most of them were/are run by Triglav National Park authorities and Alpine Association of Slovenia. 
Eighteen mountain huts were visited in summer of 2012. The analysis of information, gathered in the field, showed that renewable energy sources have important role in electricity supply. All mountain huts had solar cells, four of them had also additional wind generators. Due to karst environment, it is impossible to use water energy as water flows underground. So, the thesis Solar potential is higher that the use of solar energy can be confirmed. There are large reserves in using wind energy, too. Comparison of electricity supply in 1992 and 2012 showed that fossil fuels lost their primary role. More than half of mountain huts use electricity generators powered by diesel fuel as a backup only. Therefore, the annual consumption of fossil fuels is minimal.

We are proposing real and often easily achievable solutions for six mountain huts which were unable to provide the needed electricity from renewable energy sources only in August 2012. Photovoltaic system of Dom Zorka Jelinčiča na Črni prsti was partly destroyed by lightning. The reconstruction of photovoltaic system is now a priority solution because of mountain hut's big solar potential. Similar solution, focused on increasing battery capacity, is also recommended for Vodnikov dom na Velem polju. Triglavski dom na Kredarici is able to run on renewable energy resources only during some periods of year but not in high season in August. There are reserves in electricity production especially by using wind energy. Koča na Planini pri Jezeru and Koča pri Triglavskih jezerih have extraordinary high electricity consumption. Removal of refrigerators for beverages and replacement of cooling devices and lightning with energy efficient appliances should be priority. Kosijev dom na Vogarju is on crossroads of two totally different electricity supply options. The first one considers the connection on public electricity network, the second one the update of photovoltaic system. Due to sunshine duration on mountain hut's location and the slope and aspect of the roof, the update of photovoltaic system is recommended.

Detailed analysis confirmed sufficient potential for electricity supply using only renewable energy sources on all analyzed mountain huts. Transition from fossil fuels to renewable energy sources should also be accelerated by caring for fragile mountain karst environment. The use of fossil fuels is causing air pollution by combustion and, in a case of spill, also serious pollution of underground water.

\section{(Translated by the author)}

